\title{
A review of the determinants of a successful endosseous implants
}

\author{
Tomasz Bobek
} Anna Gordon

January, 2021

\begin{abstract}
:
The periods after the groundbreaking work of Branemark saw a rising number of dental implants. The traditional treatment of dental removal is being increasingly replaced by the modern technology-led dental implants. The insertion of prothesis, however, experience success and sometimes failure. In order to make the success rate high, there is large number of researches that attempted to the identification of the success factors of the dental implants. As the number of the dental implants are rising, it became crucial to know the success factors of the implants. The objective of our research was to review the literature to identify factors that contribute to the success ratio of the dental implants. After the investigation of the literature, we find that the success factors can be classified intro three broad classes. The first class of success factor are the factors ingirted in the patients such as gander and age of the patients. The second class of the success factors are associated with the organ itself such as the maxillary of mandibular quality. The third success factors are associated with the quality of dental operation and the combability of prosthesis. This research analyzes and discusses these three success factors.
\end{abstract}

Short biblography description:

In text citations: [1][2][3][4][5]

$[6][6][7][8][9][10][11][12][13][14][13][15][16][17][18][19][19][20][21][22][21][23][24][25][25][26]$ [27][27] [28] [29] [30] [31] [32][33] [34] [35] [36] [37] [38] [39] [40][41] [42] [43]

Authors:

1) Tomasz Bobek

2. Anna Gordon Anna Gordŭn e nauchen sŭtrudnik po fiziologiya - Fakultet po meditsinski i zdravni nauki, Universitet v Netam, Prilozhni nauki Bŭlgariya. 


\section{References}

[1] N. P. Lang and T. Berglundh, "Periimplant diseases: Where are we now? - Consensus of the Seventh European Workshop on Periodontology," in Journal of Clinical Periodontology, 2011.

[2] T. Albrektsson and C. Johansson, "Osteoinduction, osteoconduction and osseointegration," Eur. Spine J., 2001.

[3] A. V. D'Amico et al., "Biochemical outcome after radical prostatectomy, external beam radiation therapy, or interstitial radiation therapy for clinically localized prostate cancer," $J$. Am. Med. Assoc., 1998.

[4] S. Parithimarkalaignan and T. V. Padmanabhan, "Osseointegration: An update," Journal of Indian Prosthodontist Society. 2013.

[5] T. Albrektsson, G. Zarb, P. Worthington, and A. R. Eriksson, "The long-term efficacy of currently used dental implants: a review and proposed criteria of success.," Int. J. Oral Maxillofac. Implants, 1986.

[6] Q. Chen and G. A. Thouas, "Metallic implant biomaterials," Materials Science and Engineering R: Reports. 2015.

[7] M. Saini, "Implant biomaterials: A comprehensive review," World J. Clin. Cases, 2015.

[8] J. G. Naples and M. J. Ruckenstein, “Cochlear Implant," Otolaryngologic Clinics of North America. 2020.

[9] D. P. Tarnow, S. C. Cho, and S. S. Wallace, "The Effect of Inter-Implant Distance on the Height of Inter-Implant Bone Crest," J. Periodontol., 2000.

[10] R. Sanghvi and A. Gordon, "The plant-based-diet and obesity: The process and literature survey,"2021.

[11] T. Magradze, "MATHEMATICAL MO DELING IN THE ENTERPRISE MANAGEMENT," in Colloquium-journal, 2020, no. 7 (59).

[12] M. Tengiz, "NEW METHODOLOGY OF EVALUATING THE EFFICIENCY OF MANAGERIAL DECISION-MAKING," in Colloquium-journal, 2020, no. 8 (60).

[13] T. Magradze, "TAX ADMINISTRATION IN THE RUSSIAN FEDERATION: CURRENT PROBLEMS AND DEVELOPMENT PROSPECTS," in Colloquium-journal, 2020, no. 5 (57).

[14] M. Tengiz, “APPLICATION OF GAME THEORY SIMULATION IN ENTERPRISE MANAGEMENT," in Colloquium-journal, 2020, no. 8 (60).

[15] A. F. Mavrogenis, R. Dimitriou, J. Parvizi, and G. C. Babis, "Biology of implant osseointegration," Journal of Musculoskeletal Neuronal Interactions. 2009.

[16] N. P. Lindhe, Jan; Lang, Clinical Periodontology and Implant Dentistry. 2013.

[17] N. U. Zitzmann and T. Berglundh, "Definition and prevalence of peri-implant diseases," in Journal of Clinical Periodontology, 2008.

[18] L. J. A. Heitz-Mayfield, "Peri-implant diseases: Diagnosis and risk indicators," in Journal of Clinical Periodontology, 2008. 
[19] J. Lindhe and J. Meyle, "Peri-implant diseases: Consensus Report of the Sixth European Workshop on Periodontology," in Journal of Clinical Periodontology, 2008.

[20] G. Mendonça, D. B. S. Mendonça, F. J. L. Aragão, and L. F. Cooper, "Advancing dental implant surface technology - From micron- to nanotopography," Biomaterials. 2008.

[21] C. R. Arciola, D. Campoccia, and L. Montanaro, "Implant infections: Adhesion, biofilm formation and immune evasion," Nature Reviews Microbiology. 2018.

[22] A. B. Novaes, S. L. S. de Souza, R. R. M. de Barros, K. K. Y. Pereira, G. Iezzi, and A. Piattelli, "Influence of implant surfaces on osseointegration," Brazilian Dental Journal. 2010.

[23] D. A. Puleo and A. Nanci, "Understanding and controlling the bone-implant interface," Biomaterials, 1999.

[24] G. J. Christensen, “Misch's Contemporary Implant Dentistry,” Implant Dent., 2019.

[25] J. E. Davies, “Understanding Peri-Implant Endosseous Healing,” J. Dent. Educ., 2003.

[26] L. Le Guéhennec, A. Soueidan, P. Layrolle, and Y. Amouriq, "Surface treatments of titanium dental implants for rapid osseointegration," Dental Materials. 2007.

[27] C. J. Goodacre, G. Bernal, K. Rungcharassaeng, and J. Y. K. Kan, "Clinical complications with implants and implant prostheses," Journal of Prosthetic Dentistry. 2003.

[28] T. Berglundh, L. Persson, and B. Klinge, "A systematic review of the incidence of biological and technical complications in implant dentistry reported in prospective longitudinal studies of at least 5 years," Journal of Clinical Periodontology. 2002.

[29] L. J. A. Heitz-Mayfield and G. E. Salvi, “Peri-implant mucositis,” J. Clin. Periodontol., 2018.

[30] P. Papaspyridakos, C. J. Chen, M. Singh, H. P. Weber, and G. O. Gallucci, "Success criteria in implant dentistry: A systematic review," Journal of Dental Research. 2012.

[31] D. Buser, W. Martin, and U. C. Belser, "Optimizing esthetics for implant restorations in the anterior maxilla: anatomic and surgical considerations.," Int. J. Oral Maxillofac. Implants, 2004.

[32] Y. Oshida, E. B. Tuna, O. Aktören, and K. Gençay, "Dental implant systems," International Journal of Molecular Sciences. 2010.

[33] J. Y. K. Kan, K. Rungcharassaeng, K. Umezu, and J. C. Kois, "Dimensions of Peri-Implant Mucosa: An Evaluation of Maxillary Anterior Single Implants in Humans," J. Periodontol., 2003.

[34] J. G. Caton et al., "A new classification scheme for periodontal and peri-implant diseases and conditions - Introduction and key changes from the 1999 classification," J. Clin. Periodontol., 2018.

[35] S. Jepsen et al., "Primary prevention of peri-implantitis: Managing peri-implant mucositis," $J$. Clin. Periodontol., 2015.

[36] M. G. Araujo and J. Lindhe, “Peri-implant health,”J. Clin. Periodontol., 2018.

[37] C. Nelson, "Factors Affecting the Success of Dental Implants," in Implant Dentistry - A Rapidly Evolving Practice, 2011.

[38] H. S. Park, S. H. Jeong, and O. W. Kwon, "Factors affecting the clinical success of screw implants used as orthodontic anchorage," Am. J. Orthod. Dentofac. Orthop., 2006.

[39] P. Diz, C. Scully, and M. Sanz, "Dental implants in the medically compromised patient," Journal of Dentistry. 2013. 
[40] H. L. Myshin and J. P. Wiens, "Factors affecting soft tissue around dental implants: A review of the literature," Journal of Prosthetic Dentistry. 2005.

[41] M. Klein, E. Schiegnitz, and B. Al-Nawas, "Systematic Review on Success of NarrowDiameter Dental Implants," Int. J. Oral Maxillofac. Implants, 2014.

[42] S. Sakka, K. Baroudi, and M. Z. Nassani, "Factors associated with early and late failure of dental implants.," Journal of investigative and clinical dentistry. 2012.

[43] V. A. Vehemente, S. K. Chuang, S. Daher, A. Muftu, and T. B. Dodson, "Risk factors affecting dental implant survival.," J. Oral Implantol., 2002. 